\title{
The Heat Flux at the Crystallization Under Pressure
}

Richard Pastirčák, Ján Moravec, Eva Kucharčíková

Department of technological engineering. Faculty of Mechanical Engineering, University of Žilina, Univerzitná 1,01026 Žilina, Slovak Republic. E-mail: richard.pastircak@fstroj.uniza.sk, jan.moravec@fstroj.uniza.sk, eva.kucharcikova@fstroj.uniza.sk

This article deals with the influence of different specific pressures on the heat flux from the casting into the mould. The determination of the heat flux at different crystallization conditions will be the basis for the simulation calculation of the solidification with the crystallization under pressure.

The article presents the results of the measured temperatures inside of the mold and casting by influencing of the crystallization pressure of $100 \mathrm{MPa}$. For comparison, results are also presented in gravity cast specimens. Also are presented pictures of microstructure that were observed near the surface of the casting. On the basis of the measured temperatures inside of the mold are calculated as a value of the heat flow from casting into the casting mold. The results of heat flow correspond with the evaluation result of the microstructure.

Keywords: squeeze casting, heat flux, pressure, alloy AlSi7Mg0.3

\section{Acknowledgements}

This work was created within the solution of the grant project VEGA no. 1/0551/14. The authors thank the Grant Agency for support.

\section{References}

[1] JACOB O. AWEDA, MICHAEL B. ADEYEMI. (2012). Experimental Determination of Heat Transfer Coefficients During Squeeze Casting of Aluminium, An Overview of Heat Transfer Phenomena, Dr M. Salim Newaz Kazi (Ed.), ISBN: 978-953-51-0827-6, InTech, DOI: 10.5772/52038.

[2] NOVÁ, I., MACHUTA, J. (2013). Squeeze casting results of aluminium alloys. In.: Manufacturing technology. ISSN 1213-2489, Vol. 13, No. 1(2013), pp. 73-79.

[3] RAGAN, E. et al. (2007). Liatie kovov pod tlakom. Vydavatel'stvo Michala Vaška, 2007. 392 s. ISBN 978 - 80 $8073-979-9$.

[4] NOVÁ, I., NOVÁKOVÁ, I., MACHUTA, J. (2011). Aluminium alloys squeeze casting. In.: Slévárenství. ISSN 1213-2489, Vol. LIX, No. 9-10(2011), p. 304-308.

[5] MICHNA, Š., NOVÁ, I. (2008). Technológia a spracovanie kovových materiálov. Adin, s.r.o. Prešov. ISBN 978 $-80-89244-38-6.336 \mathrm{pp}$.

[6] BOLIBRUCHOVA, D. (2010). Casting technology. GEORG Žilina, ISBN 978-80-89401-14-7, 248 pp.

[7] BOLIBRUCHOVÁ, D., RICHTÁRECH, L. (2013). Effect of adding iron to the AlSi7Mg0.3 (EN AC 42 100, A356) alloy In: Manufacturing Technology. ISSN 1213-2489. Vol. 13, No. 3, p. 276-281.

[8] BRŮNA, M., KUCHARČÍK, L. (2014). Progressive method of porosity prediction for aluminium castings. Materials and technology. Vol. 48(6), 949-953. UDK 669.715:621.74:620.192.47

[9] MALIK, J., FUTÁŠ, P., VASKOVÁ,I., EPERJEŠI,Š. (2007). Vplyv technologických faktorov liatia na kvalitu odliatkov zo silumínu. Slévárenství, ISSN 0037-6825. No.4-5, p.259-262.

[10]BRŮNA, M., KUCHARČÍK, L. (2013). Prediction of the Porosity of Al Alloys. In: Manufacturing Technology. ISSN 1213-2489. Vol. 13, No. 3, p. 296-302. 